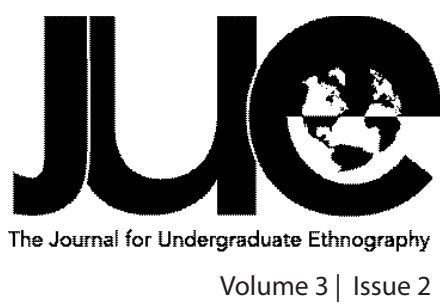

\title{
From Sitamarhi to New Delhi Railway Station:The Agricultural Antecedents to Childhood Migration in North India
}

\author{
Daniel Rosenblum \\ University of Vermont, drosenbl@uvm.edu
}

\section{ABSTRACT}

$\mathrm{n}$ India, large-scale rural to urban migrations are occurring in record numbers within the last twenty to thirty years. These migrations are inflating the populations of major urban centers such as Delhi and Mumbai. Within these streams of migrations, the number of youth leaving to cities is also dramatically increasing. At the same time, deep agricultural transformations are taking place in rural sectors, greatly altering the landscape, the opportunities available, and ultimately the livelihoods of its people.

This paper aims to address the agricultural transformations occurring in India in relation to the migration of children from rural to urban centers. With a shifting, but uneven system of landholding, climatic changes, increasing mechanization and industrialization of agriculture, and new development projects, the agrarian system in rural India is rapidly changing. Using interviews from a variety of experts as well as urban and rural informants, I will draw connections between multiple transformations in agriculture with the increase of children running away to major cities, in turn acknowledging that within this complex system of movement, there are innumerable reasons for the migration of youth. In this manner, I make clear the interconnections between issues of agriculture and other socioeconomic, political, and historical factors. This research comes primarily from extended stays in Delhi in addition to rural villages in Bihar.

\author{
Keywords: migration; youth; agriculture; development; urban \\ Acronyms: SBT (Salaam Baalak Trust); IGSSS (Indo-Global Social Service \\ Society); NGO (Non-governmental organization); HYV (High-Yield Variety)
}


INTRODUCTION: MAI AMERICA, BIHAR SE HU ( I AM FROM AMERICA, BIHAR)

The ongoing joke in Salaam Baalak Trust (SBT), a temporary and permanent youth shelter for runaways and children of or on the street, was about Bihar.

"Kahan se hai, bhai?"(Where are you from, brother?)

"Bihar."

"Kahan Bihar me?”(Where in Bihar?)

"America, Bihar."

Countless children living in the Delhi Metro Rail Corporation-owned shelter were from Bihar. Many had only come a few years ago, while others had been part of SBT significantly longer. Yet, what was intriguing was they understood Bihar as a symbol of something greater than where their first homes were. This ironic assertion by children no older than twelve, framing America within Bihar, indicates a striking self-awareness of their position in an issue that transcends the individual level. Children are running away from Bihar in alarmingly high numbers and the kids at Salaam Baalak Trust are part of that. They knew I wanted to ask about it. They had heard this chorus before.

People have been migrating out of Bihar for decades. During the Green Revolution of the 1960s and 70s, which heightened agricultural productivity in India to historically unseen levels, Biharis left for seasonal labor in the high-yield variety (HYV) agricultural areas of north India, specifically the state of Punjab (Singh 2002). The work was more consistent, the wages were higher, and the agricultural system in Bihar was becoming bleaker (Oberai and Singh 1980). In Bihar, working in the fields for only four months out of the year was no longer sufficient for sustaining growing families and payoff expenses to powerful landowners. In the last fifty years, conditions in Bihar have undergone great transformation, creating a highly unstable and notoriously "backwards" state in the eyes of the Indian federal government (Sharma 2005, 960).

More Biharis' began to leave their rural homes, moving to major cities such as Delhi and Mumbai. Leaving their homes behind in search of a more promising future, children came too alongside families, with friends, or alone. From the early 1990s through the 21 st century, Delhi's population of street children dramatically increased. A large portion of those children came from Bihar, where over 1.7 million people migrated from within the last decade (Kumar 2010). What is encouraging this migra- tion of youth from rural areas of Bihar? In order to find an answer, one must shift the focus to the rural. What transformations can we see as catalysts for a growing trend of running away? The answers to these questions are tremendously complex, multidimensional puzzles that require careful analysis of an intricate web of historical, political, cultural, and socioeconomic dynamics.

This paper will primarily focus on one piece of this multifaceted pattern of migration: the agricultural antecedents to childhood migration. Additionally, I will explore the entanglements linking agriculture transformations to other relevant complex processes. First, the research will investigate the multiple controversial definitions that constitute a street child by referencing conditions in Delhi, then move on to discuss the livelihoods of rural Indian children. Afterwards, I will trace agricultural legacies in India with a focus on Bihar, connecting contemporary concerns and future implications with this history. The discussion will shift to issues beyond agriculture, namely educational failures, casteism, and the shared perceptions of urban and rural life. These sections point to the momentous effects agriculture is having on youth migrations as well as to other internal and external factors that contribute to these profound trends of departing rural villages to urban centers. It is important to note that while agricultural transformations have contributed to childhood migration, there are also complex networks and relationships that tie agriculture to many other historical, socioeconomic, and religious mechanisms, which are all simultaneously at work. It is impossible to isolate without erasing or simplifying the intricacies that produce the complex symptoms of social crisis we see today.

\section{FIELDWORK \& METHODOLOGY}

My interest in India began in an undergraduate anthropology seminar, titled "Street Children". I created a project that involved incorporating organic, sustainable agriculture within the lives of street children in Delhi. I saw it as a possible route for redirecting migrational flows and improving the rates of repatriation among street kids. This project, with the support of my advisor, led me to apply similar concepts to an undergraduate research project. I applied for a number of undergraduate research grants, which I was awarded in my sophomore year and began to prepare during the end of my semester. I conducted 
fieldwork in India over the course of three months during the summer of 2012. My primary areas of study were in the capital, Delhi, and in the northeastern state of Bihar (see figure 1). The first month of my fieldwork was spent in Delhi, working closely with street children as well as with non-governmental organizations (NGOs) that provide care and services to many former and present-day street children. While I spent a major portion of fieldwork in Delhi at railway platforms, temple markets, and major tourist areas-locations where many street children liveI also spent significant time at Salaam Baalak Trust, an NGO that has been a presence in Delhi among street children for over twenty years. They operate numerous shelters and contact points that provide safety and care to many of the children. I volunteered at a major shelter of SBT, teaching children rudimentary English and computer software skills. At that time, I was able to gain the trust of the children and begin learning of their histories and troubles. My engagement at SBT provided crucial insight into many of my initial research questions; it also gave me time to sift through many of the pieces I heard from children on the street. Delhi presented me with a roadmap for understanding the livelihoods of these children, their survival mechanisms on the streets, and their networking and social organization. Lastly, the experience gave me a foundation to make sense of past rural migrations.

In the state of Bihar, I spent time primarily in two major districts: Sitamarhi, an area along the Nepal border notorious for child trafficking (Sakha 2012), and Samastipur a central town located on the banks of the Gandaki River. In nearby villages on the outskirts of these towns I spoke with local villagers, both young and old, about issues of running away, agricultural transformations within the villages, and their impressions of rural and urban areas. In addition, I met with organizers and children

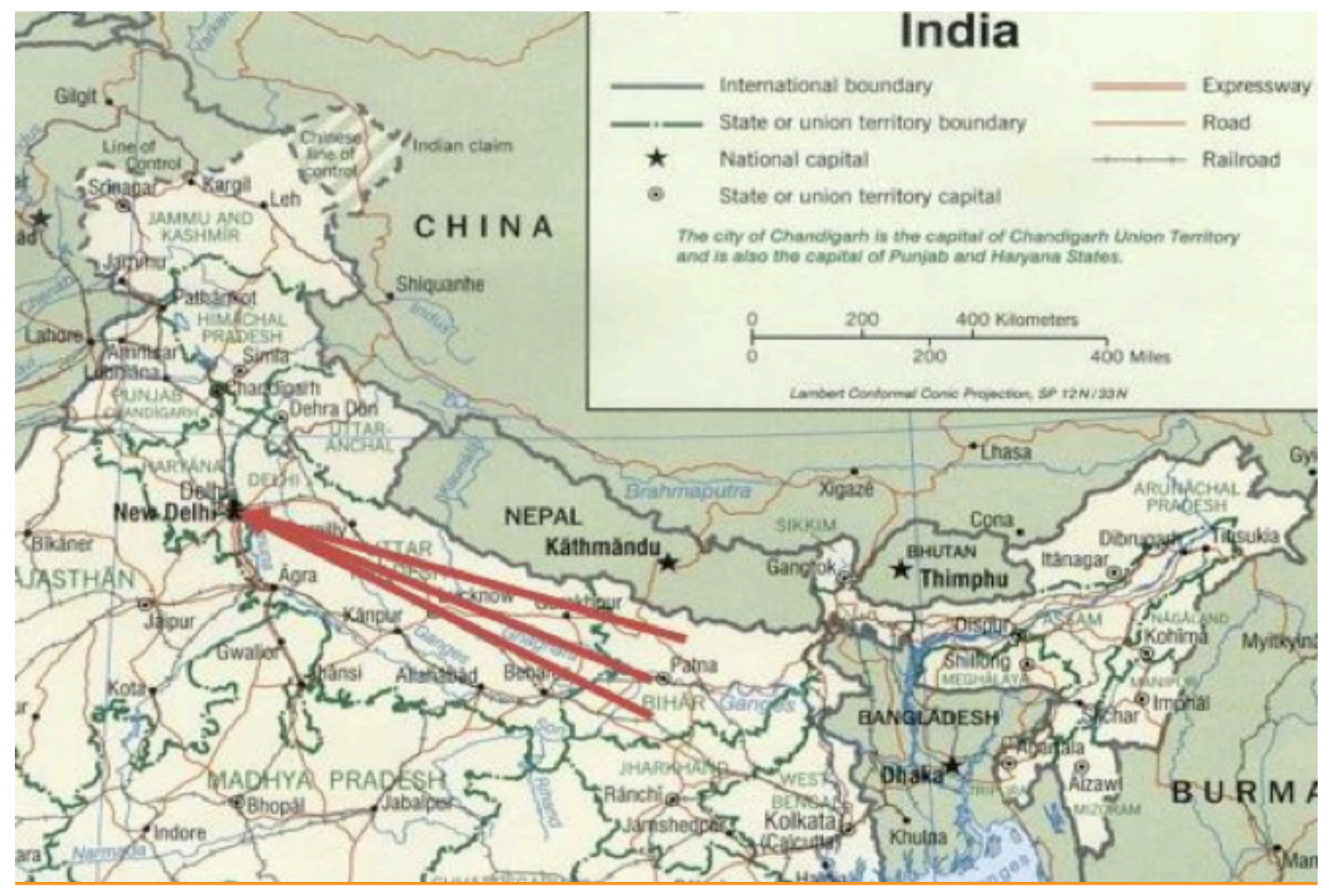

Figure 1-North India Rural to Urban Migration Corridors (India 2001). 
from local NGOs that were working to address issues of child labor and trafficking from rural source areas to major cities. In the final days of my fieldwork in Bihar, I spent time in the capital, Patna, speaking with children in a local NGO as well as on the major Patna railway junction. In Bihar, I was able to connect my experiences in Delhi with contemporary issues of rural life in a major source area for runaway children. This piece of my study provided essential links between the rural and urban, contributing to my understanding of the complexities of youth migration.

I obtained and recorded my field data through numerous methods, namely participation-observation and interviews. Alongside my participation in NGOs and in the villages themselves, these personal interactions were invaluable, helping me to interpret my research questions. Structuring my interviews as loosely-scripted or informal conversations allowed me access to specific, detailed first-person accounts of my primary foci, giving me crucial qualitative perspectives.

Much research was conducted alongside my primary informant and translator, Khushboo Jain, a Delhi-based researcher, activist, and Ph.D. candidate in sociology. Though my Hindi skills were proficient enough to hold a basic conversation, Khushboo's translations allowed me to delve deeper into the critical issues of my research. Her knowledge of Delhi's street children and organizational networks along with her unwavering passion towards making a difference for the children of Delhi proved to be essential. Her input was critical, constructive, and a major force in the success of this project.

\section{THE STREET CHILD}

Before exploring the roots of childhood migration in rural areas, it is vital to establish a clear definition of the term "street children". As Panter-Brick notes, the situations of street children are far from homogenous. Street children come from a wide variety of backgrounds and circumstances, so much so that the term often fails to encompass all of the diverse lifestyles of children who are "on or of" the street (Panter-Brick 2002). ${ }^{1}$ Children come to Delhi in countless modes: family migrations, alone as solo children, trafficked into a workplace environment, among others. It is impossible to capture these diverse passageways to street life with one term. These complexities extend further into the representation of identity on the street itself. Here, selfidentification by these children tends to challenge their so-called status as "urchins" or "street dwellers." No child conforms to a single fixed identity. Rather, they resist such categorical labeling through day-to-day actions and a unique system of livelihood making.

In Delhi, the estimated number of street children ranges widely as a result of differing criteria for what constitutes a street child. A recent Save the Children study, titled Surviving the Streets considered over 50,000 children street kids, despite the fact that over $70 \%$ of those children were known to have a home somewhere in Delhi (Bhaskaran and Mehta 2011). Other estimates from SBT claim upwards of 100,000 street children in Delhi. This increase is part of a much larger growth number of street children in India, where there are an estimated 18 million currently on the streets (Butterflies 2011, "Situation of Street and Working Children in Delhi"). ${ }^{2}$

Delhi's street kids live in a variety of ways in order to maintain their livelihoods. For children living in railway stations and platforms, a frequent occupation is "ragpicking," (see figure 2) which involves the collection of plastic bottles in railcars using large nylon sacks (Steinberg 2012). This simplistic description, however, fails to do justice to the meticulous organization and skill required in collecting bottles. Children keep precise track of train schedules, positioning themselves on the tracks to hop on the train right when it arrives. The fastest pickers will be at the head of the trains while the slower ones stay at the back, giving them more time before the train workers move through the cars. The children usually work with others on their platform, typically pooling the total amount of bottles at the end of the day, when they are sold to a 'middleman' who pays the children en masse. The 'middleman' then returns the bottles to a recycling center where they are processed. Other earning options for street children typically involve food service in establishments like dhabas, tea stalls, and restaurants. Others work as domestic servants for civil society (Butterflies 2011, "My Name is Today. Butteflies: Programme with Street \& Working Children”).

For girls, however, being in the public eye puts the family's honor in question due to the risk of impropriety. Frequently, girls who enter the urban landscape are quickly swept up and recruited into elaborate prostitution circles (Huberman 2006). While girls and boys have differing subsistence strategies on the streets due to cultural expectations and norms, one must look beyond material livelihoods to see deeper connections on the street.

Alessandro Conticini's study noted that for street children 
in Dhaka, "a feeling of love and trusted friends" and "cooperation" were found to be the most important things in daily life (Conticini 2007, 84-94). Supportive, yet frequently exploitative social networks and relationships are found across all groups of children on the streets of Delhi. Children on the railways tend to identify with a particular platform and have a certain social circle with whom they share money, food, and sometimes drugs. ${ }^{3}$ Such tight-knit social circles also exist in temple markets such as Kalkaji Mandir in Delhi. Children often sit on the steps of the market begging for alms of money and food. After collection, the children head to one of the pathways out of the market where they pool and share their take, talk, and simply play around. The livelihoods of street children transcend basic survival through their complex relationships and social networks. These children provide social inclusion for one another in social and political structures that have historically rejected their presence, displaying solidarity with others who have had similar experiences.

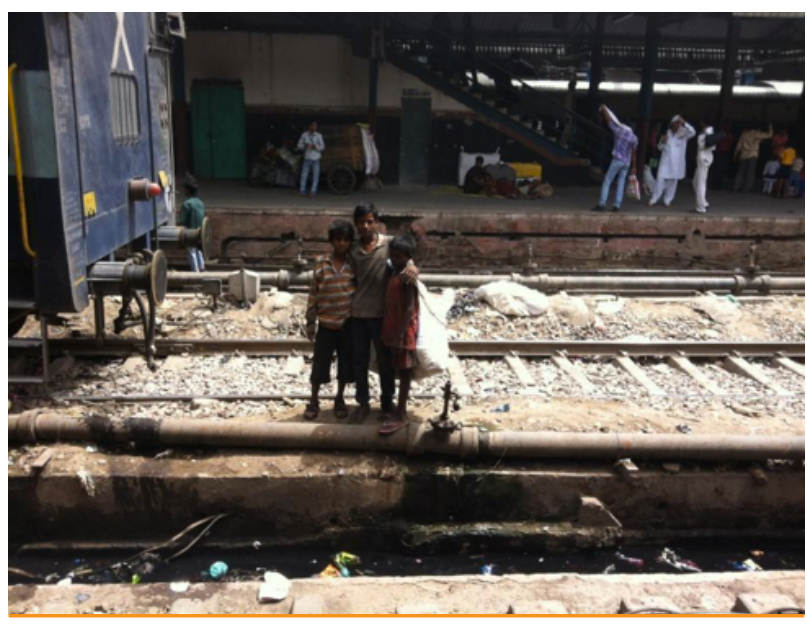

Figure 2-—"Ragpicking" along the tracks in Old Delhi Station.

\section{BEFORE THE STREETS: LIVELIHOODS IN RURAL BIHAR}

Today, the children of rural Bihar are more connected with the rest of the world than ever before. The skyline of the district town of Sitamarhi, a place that sits some twenty miles from the Nepal border, is littered with cell phone towers. On the streets below, the walkways are filled with mud, trash, and cow dung. Passersby trudge through the mess to buy fly swarmed mithai (sweets) and sweltering fruits at nearby stands. The children of Sitamarhi live in this contrasted space-the severe juxtaposition of a unique "modernity" and urbanization with dilapidated infrastructure surrounding them. The villages within five miles of the district town scarcely receive electricity, prompting me to wonder how anyone with a cell phone is able to recharge their phones. ${ }^{5}$ The villages I spent the majority of my time in, Amritpur and Baksampur, ${ }^{6}$ gave insight into the livelihoods of children in rural Bihar. In Amritpur, every corner and passageway of the village seemed to reveal more and more children. At times, it appeared that the ratio of children to adults was ten to one. Many of these children had prominent signs of malnutrition: kwashiorkor, stunted growth, and slowly healing infections (Bhutta, et al. 2008; Som, et al. 2007). One boy of about twelve, Deepak had a nasty infection on his lower leg that continued to worsen over the week I visited. However, there was no formal doctor in the village, only someone trained in basic medical practices. He would have to go to Sitamarhi town to be given medicine, which would cost too much money for Deepak's mother. This was a problem all too common for children of rural Bihar.

School quality and attendance throughout Sitamarhi district was quite mixed. A government school I visited in Amritpur was highly understaffed, lacking proper materials and facilities, and seemed more of a social gathering point for youth. Children sat along the walls with other classmates drawing, talking, and laughing while the teachers and administrators sat impotently near the entrance, splitting their time between socializing and supervising (see figure 3 ). When we arrived, the teachers began to complain of uneven wage scales and low salaries, citing this as an explanation for the chaos at the school. Another school we visited in Baksampur, however, which was run entirely by women, had sufficient materials, was properly staffed, and seemed to be extremely beneficial for the students. In both cases, there was a noticeable tension between attending school and working at home. Many children, especially older ones, 


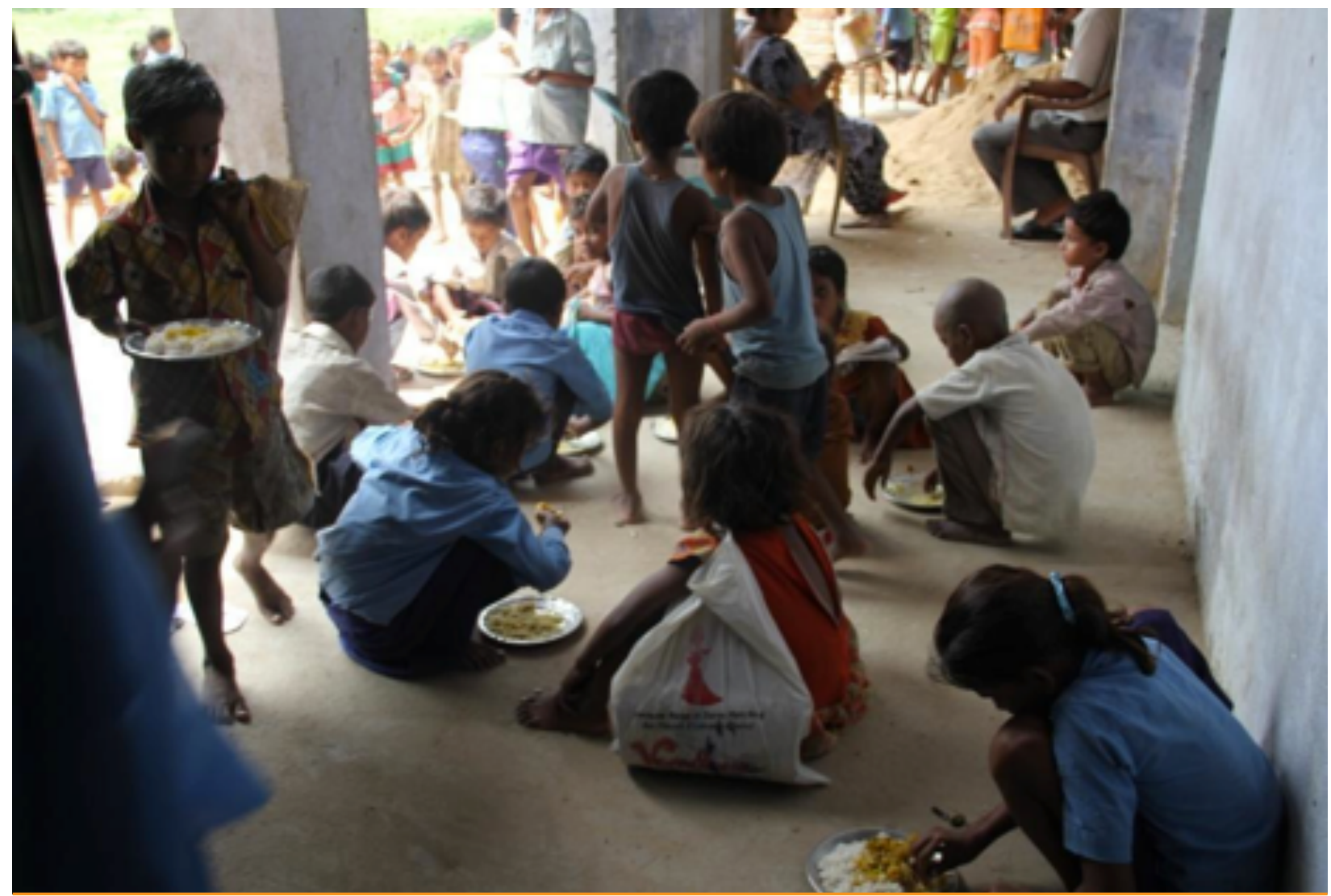

Figure 3-Lunch at an Amritpur government school. Photo Credit: Khushboo Jain

work in the mornings, helping to transplant rice, and then check into school for the second half of the day. In some cases, children would stop attending school entirely in order to help at home, such as with Hoja, a lower caste girl in Baksampur. Hoja, who was 14 or 15, claimed her family was too poor and her mother needed help taking care of her younger siblings. As her siblings grew older, pressure on Hoja to earn began to outweigh the importance of schooling. This pressure led Hoja to abandon her education in order to help her family. The livelihoods of Bihari youth were rapidly transforming, surrounded by newly "modern" pursuits and desires within a rural structure and community. These developments imply a growing understanding and connection between urban and rural environments, one that has put increased pressure on youth to earn and sustain others, which in many cases means moving away from rural homelands.

\section{TRACKING AGRICULTURAL TRANSFORMATIONS}

Bihar's agricultural history is extremely complex, interwoven with transforming government policy, development, and increasing mechanization of the agrarian system. Prior to the Green Revolution ${ }^{7}$ taking hold in Bihari agriculture, there was a structure of landholding: the Zamindar system, institutionalized under the British Raj. The system's abolition, however, is what I wish to focus on, in terms of the uneven effects it had on rural villages, landholdings, and landlessness. The zamindari was a system of landholding that consolidated fields in the hands of 
powerful village elites. For Bihar, this meant most of the land fell in the hands of upper caste Hindus (Chaudhry 1988). Peasants were then typically tied to the land, working for the grain they produced, while remaining landless themselves. In the late 19th century, however, Bihar began to feel the effects of commercialism due to colonial expansion from the west, beginning a process of out-migration from both the zamindar and lower class populations. In the Chapra region at the beginning of this century, upper castes had to resort to occupations other than agriculture. Rajputs, an upper caste group, went out for 'service' along with lower class individuals, becoming "peons and durwans in estates of larger zamindars" (de Haan 2002, 120). Out-migration occurred in high numbers during the zamindari system for both landowners and lower caste laborers, yet the economic gaps between landowners and lower class, as well as the frequency of migration, seemed to increase after the foundation of India and the subsequent abolishment of the colonial landholding system.

Due to the federal government's abolishment of the system in 1948, and the subsequent Bihar Land Reform Act of 1950, the system was slated for reformation. But the redistribution of land was extremely gradual, and in 1964 the India Planning Commission acknowledged that peasants were still heavily employed as sharecroppers, and that "supervision over the staff need[ed] to be tightened and vigorously enforced" (Council 1966, 47-8). Many powerful local leaders in Bihar resisted redistribution, impeding the progress of implementation that the Planning Commission hoped to see (Chaudhry 1988). This resistance was also seen in Uttar Pradesh, where thakurs (landowners) "continued to dominate villages politics," despite tenants being sold new property for cultivation after the zamindari abolition (Gupta 1998, 112-13).

While the abolition of zamindari signaled a dynamic change in landholding practices, major landowners continue to wield power in the village. In Amritpur, the son of a former zamindar named Sharma expressed how he was forced to divide up his 60 bighas $^{8}$ worth of land. "Yet", he said, "we see overall that we're in a good state. None of our kids need to buy land, as such, we are pretty well off." Sharma also explained that one of his sons now lives and works in Delhi and another is in the army. However, poorer villagers we spoke with in Amritpur expressed concerns with the power of landowners. One man I spoke with at a tea shop poignantly stated that, "zamindari is not practiced anymore but the zamindar still has the money." ${ }^{10}$ Sharma's land, for example, is still cultivated by lower caste individuals, who typically have marginal, if any, landholdings of their own. Similarly, in Baksampur, landownership by the lower class is still very insignificant. A Chamar ${ }^{11}$ caste family we spoke with expressed how the powerful landowners rent land to them. ${ }^{12}$ The land is big enough to establish a permanent residence for their kaccha home (made typically of mud, bamboo, and leaves), yet the land they cultivated is still all owned by the former zamindar. One of their sons, Monu, who was only ten, had recently been running away for days at a time to Sitamarhi town, where he would beg for food and then return home a day or two later. His parents expressed concern that he might continue to runaway to farther locations for longer periods of time. As these examples demonstrate, the uneven abolition of the zamindari system has had lasting effects on the landscape of Bihar, contributing to current power relations in rural villages. The wealth gap between many lower class villagers and landowners widened in many cases, leaving a legacy of instability in rural villages as well as bringing a new stream of young Biharis into Delhi.

The Green Revolution in Bihar has been accompanied by a large increase in the mechanization of agriculture. Much like in the state of Punjab twenty years prior, farming practices and techniques are shifting, leading to a larger dependence on HYV seeds. In turn, more inputs-such as pesticides, herbicides, and water-are needed to maintain these modified seeds. At Sharma's farm, they recently switched to a new seed, called shree vidhi, which is supported by a government plan. The new seed is purchased and replaced every year, as its modification does not allow regeneration (such seeds are colloquially referred to as 'terminator seeds'). With the modified seed, more water and pesticides are needed, which "when sprayed, some portion of it fell on the vegetables, and if that is eaten in the next 3-4 days, it has harmful effects, like kidney and liver destruction and so on." 13 Sharma also made the distinction between crops he sells versus the ones he eats. Rice sold to the market is the hybrid variety that uses shree vidhi seeds, while "for our consumption we cultivate a different variety" that smells and tastes much better. ${ }^{14}$ In the Amritpur tea shop many villagers expressed concerns over increased inputs yet granted that yields were higher: 


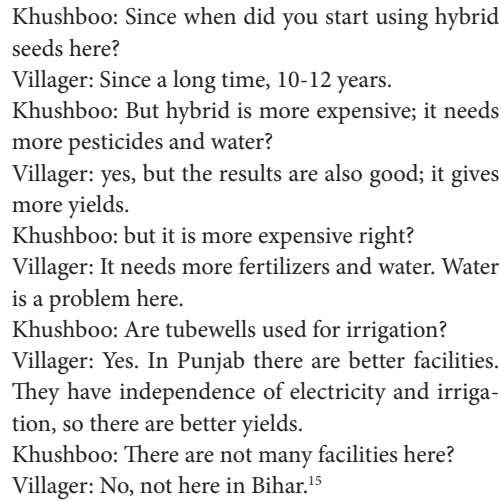

In the short term, the HYV seeds are paying dividends despite increased costs for fertilizers, pesticides, water, and machinery. However, if one takes lessons from Punjab's Green Revolution, one can see the grave environmental and social impacts that come with higher yielding crops. Vandana Shiva's Violence of the Green Revolution raises concerns about the intensification of inputs in farmland as well as the marginalization of small farmers and landowners due to increasing industrialization. In Punjab, the primary beneficiaries of the "revolution" were large agrochemical companies and the large farmers that could afford the inputs, while the majority of the population was exploited (Shiva 1991). Lower class farmers and laborers were unable to access these new technologies, an inequity that contributes to a widening wealth gap, while larger farmers continued to inflict extreme harm on the local environment.

In Bihar, almost twenty years later, similar issues are being revisited. Distribution of these new industrial technologies is unequal, resulting in the recalling and recapitulating of the zamindar system of the past. Large landowners are the only ones able to afford shree vidhi seeds, new inputs, and more machinery. One of my primary informants, Indu Prakash of the Indo Global Social Service Society (IGSSS), felt "a new business model of agriculture" has arrived, "destroying the traditional base of agriculture" in rural Bihar. ${ }^{16}$ Profit models and scientific data, which are unfamiliar to rural villagers involved in agriculture, have become the key for success in agriculture. Small farmers are forced into this commercial system with the rising price of cultivation, "compelled to adopt high- yielding crops and technologies in order to pay rents and service debts" (Wilson 2002,
1237). Access to high-yield technologies and inputs typically lies in the hands of large landowners, meaning marginal farmers remain dependent on the services of a minority of powerful landowners, contributing to a dominant power structure that inhibits the livelihoods of small farmers (ibid). With the prices of crops decreasing despite production and yield increasing, farmers must work more over the course of the year to sustain their livelihoods.

Through the usage of HYV seeds alongside newer, more expensive technologies and inputs, small farmers suffer at the hands of large landowners and are forced to make sacrifices. While yields and monetary gains are initially higher, in the long term the system will actually inflict more damage on the small farmer, as part of what Indu Prakash termed, "a flawed developmental priority for the country." ${ }^{17}$ This development system has and will continue to marginalize small farmers and lower class individuals, while engendering an unsustainable dependency model that saps fertility from the land. As a result, many are forced to migrate to urban centers in search of better economic opportunities and alternative livelihoods from those rendered untenable in rural villages.

A source of alarm in recent years regarding all areas of India's north and northeast plains is climate change. The areas around the Ganges River continue to suffer more pollution, contributing to the severe climate transformations occurring in the Ganges Delta region, which empties into the Bay of Bengal (Acharyya, et al. 1999; Harvey 2002). Bangladesh and West Bengal continue to experience extreme climate variations, including large-scale flooding, extreme heat, and natural disasters (Ali 1999; Karim and Mimura 2008; Mirza, et al. 2003). In Bihar, as well, climate is very much a concern. As we drove from Patna to Sitamarhi district, I was struck by the flooding. High walls of water reached the admixture road of dirt and gravel, coming dangerously close to a vulnerable gas station. Meanwhile, rice fields sat submerged many feet below alongside the owners' saturated kaccha homes. In Bihar, agriculture depends heavily on monsoon rainfall, which in recent years has become erratic, unpredictable, and uneven in its distribution (FMIS 2011). As a result, flooding has become a much more frequent event, sometimes rendering areas of Bihar inaccessible for months at a time. With such unpredictable, yet steadily increasing flood rates, crop productivity will inevitably take a hit. For example, 
in a study of the 2004 flooding in Bihar, 22\% of agricultural land was reported as ruined (Chandran, et al. 2006, 253). This trend is expected to increase over time, with a decrease in wheat yield of 5-6\% percent by 2080 due to sporadic monsoons and an overall increasing maximum temperature (Kumar, et al. 2011, 171). In addition, with the construction of a dam in Nepal, water flowing into Bihar from the Baghmati River has become increasingly unpredictable. According to Sharma, "after the dam was built and when the dam bursts, all the water goes in one direction with full force." The dam's presence has exacerbated monsoon flooding, making these situations increasingly hard to predict. This has inundated countless fields, destroying crops, while crippling the livelihoods of rural Bihari farmers. With these increasingly unpredictable monsoons and droughts coinciding with elevated pollution levels, families who rely on agriculture must make crucial decisions to maintain their livelihoods. Sometimes this means suffering losses and taking loans. Other times, it means uprooting from rural homelands and heading to new opportunities in cities.

In Sitamarhi district a sugarcane processing plant dominates agricultural production, contributing to the monoculturization of sugarcane in the surrounding villages (see figure 4). Monoculturization is defined as the practice of replanting the same crop species in the same field with no crop rotation. Frequently, this process leaves crops vulnerable to epidemics, as it is much easier to transmit diseases between the same plant species rather than across a diverse set of crops. In Sitamarhi, farmers dedicate large portions of their fields to this labor-intensive crop due to the demand from the factory. This industrial development is part of the neoliberal movement of the 1990s. New policy opened up the country to development projects, allowing private foreign and domestic companies to start production in many former agricultural lands. However, unlike the states of Jharkhand and Orissa, which benefit from their rich deposits of lumber and coal, ${ }^{18}$ Bihar is largely left alone from industrial development. The state is known for its fertile agricultural land rather than its extractive resources, meaning industrial development is not a primary interest for the Indian government. This leaves Bihar citizens with crucial decisions to make. If there is no impetus by the government to aid in a more egalitarian model of development, then unevenness emerges. People are forced to migrate to pockets of development in Jharkhand and Orissa, leaving their homeland behind. Thus, one can see how this uneven development model is unsustainable and highly damaging. As Indu Prakash states:

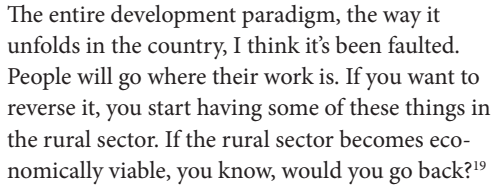

For rural Biharis who lack opportunities on their land or on the fields of large landowners, it may be more feasible to go out and find a more consistent job. Bihar's youth population is compelled to follow this paradigm. Working in the fields is not only unviable, but it is unattractive as a job. Many teenagers expressed to me how they would prefer to have a job working in the city, rather than being a farmer. A discussion with several young men in Amritpur revealed that the majority work in the district towns or in major urban centers because that is where they find most jobs. They only come home to farm for a few weeks before they return to their urban jobs. They see no future or possible channels of development in Amritpur, and believe farming is not a fulfilling profession anymore. Instead, they desire to go to where development exists in order to find work..$^{20}$

With privatization and deregulation playing an increasingly larger part in the Indian economy, the spread of uneven development is on the rise (Kumar 2008; Pandit 2012). Pockets of investment take precedent over undeveloped regions, many of which are in Bihar, resulting in the relocation of jobs to specific concentrated development regions. An area failing to receive direct investment is not able to hold its inhabitants due to the lack of opportunity, signaling an inevitable out-migration. These migrations tend to move exactly in synch with investment patterns (Deshingkar 2006; Henderson 2010). Men and children constitute a significant portion of these migrational flows in their search for opportunities beyond a depressed agricultural system. At the same time, development policy is reshaping how the Indian government values agriculture. Under the neoliberal economic policy, agriculture is becoming integrated into a structure that relies on policies of investment, incentives, and innovations. This system no longer allows the agricultural sector to strive for self-sufficiency. It is now connected to a larger world economy. And without crucial investment in these Bihari agricultural 
zones, it reaffirms the impossibility of working and living solely on one plot of land. Adults and youth have no choice but to head where development is promoted and incentivized-the zones where jobs and consistent opportunities exist.

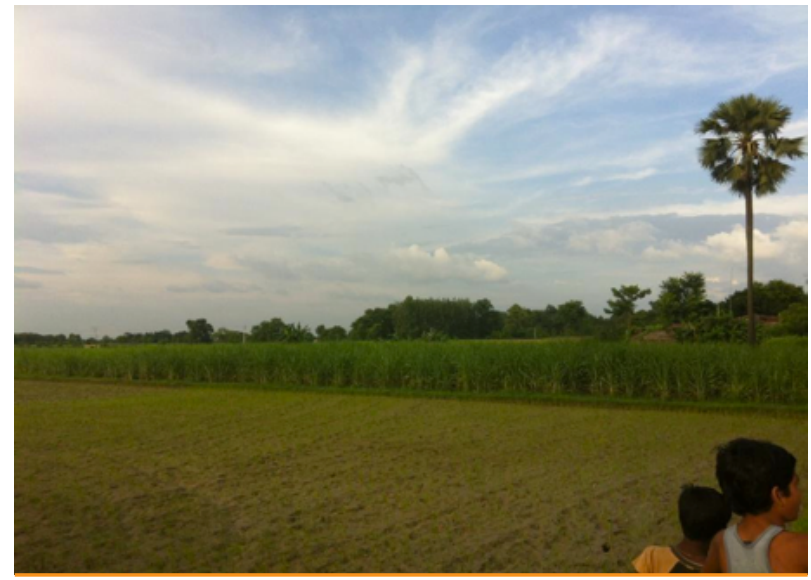

Figure 4-Sugarcane fields in Amritpur village, Sitamarhi District

\section{BEYOND AGRICULTURAL MIGRATION}

While agriculture has played a crucial role in the transformations within Bihar over the last fifty years, it would be narrow-minded to deem this the only factor contributing to higher frequencies of youth migrations. Rather, these agricultural transformations involving issues of landholding, mechanization, climatic changes, and development need to be understood as intertwining processes which interact with other socioeconomic, historical, and religious dynamics. By examining the dense linkages that tie other critical social issues with agriculture, one can begin to see the extreme complexities of youth migration. In this section, I will discuss three significant topics that reoccurred in my fieldwork: rural education failures, the caste system, and the shared perception of rural versus urban lifestyles.

\section{Rural Education Failures}

For years there has been constant pressure on Bihar's government and Chief Minister Nitish Kumar to improve rural education. Kumar has actually drawn praise from many critics for his first term, during which the state government provided much needed infrastructural improvements for Bihar's youth (Ghosh 2012). In Sitamarhi district, many rural villagers expressed how the educational system has improved significantly in the last decade. The grandfather of a Bhumihar ${ }^{21}$ family in Baksampur, an upper-caste landowner, informed us that "boys are all going to school now. Earlier they use to rear sheep and buffalo, but now they are getting books, clothes, cycles for free, and so they have started taking an interest in going to school."22 These improvements are encouraging more children than in the past to attend school. Yet the quality of education remains inconsistent. Many children still become de-motivated or uninterested in their studies and consider leaving school altogether. A large portion of students drop out before they turn fourteen, the age of guaranteed education under India's Right to Education Act (Parliament 2012).

Additionally, as I mention above, the schools I visitedwith one exception-tended to be chaotic, understaffed, and unstructured. Teachers were rarely conducting lessons, students lacked appropriate books and materials, and the buildings were typically unsuitable as educational facilities. Many students failed to stay the entire day while others came in late after helping their parents at home or in the fields. This is quite similar to Sainath's description of Bihar's schools some thirty years earlier in Everybody Loves a Good Drought, where many schools suffered from the exact same issues (Sainath 1996, "This is the Way We Go to School"). The rural education system in Bihar, despite making strides under Chief Minister Kumar, has failed to match the standards of the urban centers of Delhi and Mumbai, where primary education tends to be significantly better. As a result, many rural children and their parents fail to see value in education compared to obtaining a job. The lack of a supporting educational structure sets a foundation (or lack thereof) for an unstable rural livelihood, pushing children towards the cities in search of better opportunities.

\section{Issues of Caste}

In rural Bihar, caste is still very prevalent, producing systems that limit access for many marginalized groups. Historically, the zamindari left many lower-caste families with little to no land, even after abolition in 1948. This made many lower caste families dependent on higher caste landowners for work, food, and ultimately their livelihoods. Even today, lower-caste people face intense discrimination. Hoja, the Chamar caste girl who was our guide in Baksampur, faced direct discrimination from the Bhumihar family I interviewed. Hoja was forced to stand at the periphery of the conversation, exposed to the sun outside 
the cover of the porch. Two to three feet away, sitting comfortably, members of the Bhumihar family discussed the practices of untouchability they continue to follow:

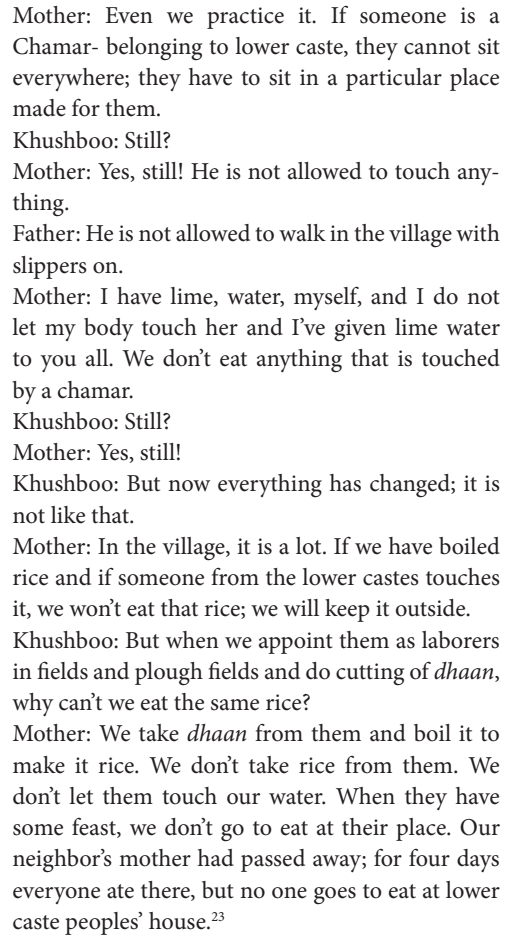

This conversation, while effective in capturing a few examples of caste discrimination in Baksampur, fails to reveal the full extent of persecution and marginalization of lower caste people in Bihar. Lower caste adults, who try to escape persecution in their village by attempting to start a business in a district town, still face discrimination. Many times higher caste individuals from their village come into town in order to reveal the shop owner's status to the public, essentially ruining any future business. At certain schools, lower caste children are forced to sit on the floor, while upper caste youth are given chairs. Additionally, teachers give upper caste children preferential treatment, despite stipulations against these actions in India's education acts. This treatment is very significant when discussing youth migration to urban centers. Casteism is practiced much less in Delhi, though it does still does exist and can be observed across socioeco- nomic lines. Caste is less of an issue in a city of migrants, where many children can hide their status. On the railways, at temples, schools, and in homeless shelters, caste is less significant, allowing for a greater chance of socioeconomic mobility and escape from caste-based marginalization. Children have more access and azadi (freedom) in the city, and are not defined by caste the way they are in rural regions of Bihar.

\section{Shared Perceptions of Rural versus Urban Lifestyles}

When asking street children, both in NGOs and on the street, what comes to mind when thinking about life in the city, interviewees tended to repeat the same descriptors: freedom, excitement, money. On the other hand, when we discussed the rural, many kids frequently described it as poor, boring, and restrictive. Among children in Delhi and rural Bihar, there is a consistent perception that the urban environment is busy, entertaining, and a perfect place to earn more money. Working on farmlands at home is monotonous and unattractive, lacking many economic benefits. A similar sentiment is understood in the style of those who straddle both urban and rural environments, something Akhil Gupta notes in Postcolonial Developments. "Clothes made the man a villager or a city slicker. What a person wore signified not merely how wealthy he was but where he belonged as well" (Gupta 1998, 85). Dress is crucial in distinguishing one's status. In Sitamarhi, those wearing the traditional dhoti are viewed differently than those in Western business clothes, typically a button down, collared shirt, and slacks or jeans. With Western clothes, a certain bravado is produced, which one is not permitted to access if they have never experienced the city. The men who return to the villages from urban centers, many of which I met through the NGO, Pratham, had an air of confidence in their demeanor. One of our guides, Vikrant, who is twenty years old, ran away to many of the major cities years ago, but has since returned after being taken into the organization. At his home in Amritpur, he is no longer the child that left, but the man of the house. After experiencing the city, he is entitled to this privileged position in the family. He is expected to provide for the family, which was obvious in both his dress and demeanor. Wearing a clean, white button down shirt and jeans, he stood out from other boys in his village, most of whom wore tattered t-shirts and shorts. His movements, and the way in which he spoke to his kin, primarily his mother and older brother, indicated his power within the family unit. Unlike 
his brother, a day laborer in the district town, Vikrant had gone to the city, earned, and decided to return.

Earning and ideal occupation are two other factors that create a binary between the rural and urban landscapes. In the cities, one can earn more money in a short time span, doing work other than farming. There is more opportunity for social mobility in the urban than in the rural environment. In my discussion with the young men mentioned above, several of them said they have no interest in agriculture or living in the village. Farming promises low wages, longer working hours, and less satisfaction. A few of them also expressed the view that farmers are uneducated as compared to people who work in the city and have wage-based jobs. ${ }^{24}$ Leaving the village, at least for young men, has become a route to respect and power within the village; being a man of the city is a desirable trait, that when coupled with the perceptions of a rural livelihood, seems all the more attractive. Children, who are exposed to these value systems, observe older men return to the villages and see going to the city as something exciting, different, and a way to improve their socioeconomic status. In this line of thought, running away is not only realistic, but a respected option for many children.

\section{CONCLUSIONS}

At one point in my fieldwork in Bihar, I grew intensely frustrated with the research process. All of my neatly wrapped, perfectly fitting ideas and answers had been twisted, contorted, and bent into something barely resembling what I began with. I had to shift my framework and examine the issue from a new angle, seeing running away as something beyond a system. The complexities of youth migration in India stretch across multiple academic disciplines, spanning large swaths of not just physical landscape, but also mental geography. It is not, and will never be a single-dimensional issue, but rather one riddled with paradox and contradiction. Embracing these intricacies, however, is a crucial step in making sense of this process. We must acknowledge that the dense layers are part and parcel of the stories of running away. The agricultural transformations occurring in Bihar, and throughout large parts of India, are quite significant when one traces historical parallels. These events and histories are foundational to the contemporary state of agriculture and village life, contributing to instability, uneven growth and development, and ultimately the fracturing that supports such a pronounced system of running away for the rural youth. The life of a street child has much to do with the rural past, beginning long before the topic became a subject of social research. However, one must simultaneously realize that developing histories and new concerns become inseparable pieces of these past histories, emerging hand and hand-not separately-as reasons for running away. It is in these increasingly complex mazes and puzzles that a more human picture materializes; a picture in which the story of running away reflects a child's pursuits, goals, and hardships rather than an alienated model. 
1. See also Glauser's "Street children: deconstructing a construct." Constructing and reconstructing childhood.

2. See also Hecht's discussion of the inflation of numbers in At Home in the Street: Street Children of Northeast Brazil, page 100.

3. In Delhi, there was little intermingling between platform groups. Many times, platforms would refuse to speak with Khushboo and I due to the fact she was speaking with children from a platform they didn't particularly like. 4. While modernity can be defined differently depending on context, for the purposes of this paper, modernity refers to Western notions of technological progress and innovation that is many times conflated with development.

5. There were a surprising number of people with mobile phones in Sitamarhi district. I spoke with children no older than ten who had mobile phones as well as grandparents who used their phone to speak with their children living in distant cities. I should note, as well, the cell phone service in Sitamarhi was the best I had had throughout all my research.

6. Names of people and villages noted in this paper have been changed to protect identities.

7. The Green Revolution was a government program that involved the introduction of high yield variety seeds into the Indian agriculture system. It first began in the late 1960s and early 1970s in the state of Punjab. The system improved the productivity of agriculture via newly adopted practices that incorporated new facilities, systems of credit, seeds, fertilizers, and pesticides. The program's importance is most clearly seen in the sheer quantity of land engrossed by HYV production. According to one report, "during the 1966-1967 crop year only 4.66 million acres (2.2 per cent of the total area under paddy, wheat, maize, jowar, and bajra) were seeded under the H.V.P [high-yield variety program], but by 1968-1969 the area under the H.V.P. had increased to 22.97 million acres (10.4 per cent of the total cultivated area under the five cereals)" (Chakravarti 1973, 320). It has only increased in size and scope since then, expanding to territory outside of Punjab, such as into Bihar. Despite yield increases, the Green Revolution is also responsible for dramatic shifts in soil fertility, land ownership, the use of inputs, and, some even say, ethnic conflict (Shiva 1991).

8. Unit of measurement commonly used in India that can vary considerably across regions. In Bihar, 2 to 3 bighas was about one acre.

9. Interview with landowner, son of former zamindar, Sharma- July 24th, 2012 in Amritpur village, Sitmarhi district.

10. Conversation with villagers in tea shop, July 28, 2012, Amritpur, Sitamarhi district.

11. Historically lower scheduled caste, known as untouchables or dalits.

12. Interview conducted July 27th, 2012 in Baksampur village, Sitmarhi district with Chamar family.

13. Interview with landowner, son of former zamindar, Sharma- July 24th, 2012 in Amritpur village, Sitmarhi district.

14. Ibid.

15. Conversation with villagers in tea shop, July 28,2012, Amritpur, Sitamarhi district.

16. Interview conducted August 14, 2012 with Indu Prakash (IGSSS) in New

Delhi.

17. Ibid.

18. In Jharkhand, a joint venture mining project between Indian and Canadian companies operated through accumulation by dispossession. First displacing the residents who were dependent on the land, the mining companies then offered jobs to many of the residents to work at the mine. However, the mine 
is only supposed to last for forty-five years, meaning "Godda will have a lot of people with no agriculture to fall back on and no jobs in Rajmahal" once the project has finished (Sainath 1996, 264, "Crime \& No Punishment"). While this type of development raises huge concerns for those living in Godda,

Jharkhand and future livelihoods without agriculture, it is also alarming for Bihar, into which no investment or funds are being funneled.

19. Interview conducted August 14, 2012 with Indu Prakash (IGSSS) in New Delhi.

20. Discussion with young laborers in Amritpur village, Sitamarhi district, July 28, 2012.

21. Hindu Brahmin caste, that were historically landowners.

22. Interview with Bhumihar family, Baksampur village, Sitamarhi district, July 27th, 2012.

23. Ibid.

24. Discussion with young laborers in Amritpur village, Sitamarhi district, July 28, 2012. 
This work is licensed under a Creative Commons Attribution-

NonCommercial-

NoDerivs 3.0

Unported License.

\section{BIBLIOGRAPHY}

Acharyya, SK, et al. "Arsenic Poisoning in the Ganges Delta." Nature 401.6753 (1999): 545-45. Print.

Ali, A. "Climate Change Impacts and Adaptation Assessment in Bangladesh." Climate Research 12 (1999): 109-16. Print.

Bhaskaran, Reshmi, and Balwant Mehta. Surviving the Streets: A Census of Street Children in Delhi by the Insitute for Human Development and Save the Children. New Delhi: Save the Children, 2011. Print.

Bhutta, Zulfiqar A., et al. "Kwashiorkor and Severe Acute Malnutrition in Childhood ? Authors' Reply." The Lancet 371.9626 (2008): 1749. Print.

Butterflies. My Name Is Today. New Delhi Butteflies: Programme with Street \& Working Children, 2011. Print.

---." Situation of Street and Working Children in Delhi." Butterflies Child Rights 2011.

Chakravarti, A. K. "Green Revolution in India." Annals of the Association of American Geographers 63.3 (1973): 319-30. Print.

Chandran, R. V., et al. "Flood Mapping and Analysis Using Air-Borne Synthetic Aperture Radar: A Case Study of July 2004 Flood in Baghmati River Basin, Bihar." Current Science 90.2 (2006): 24956. Print.

Chaudhry, Praveen K. "Agrarian Unrest in Bihar: A Case Study of Patna District 1960-1984." Economic and Political Weekly 23.1/2 (1988): 51-56. Print.

Conticini, Alessandro. "Children on the Streets of Dhaka." Livelihoods at the Margins : Surviving the City. Ed. Staples, James. Walnut Creek, CA: Left Coast Press, 2007. 272 p. Print.

Council, Land Reforms Implementation Committee of the National Development. Implementation of Land Reforms. New Delhi: Government of India Planning Commission, 1966. Print.

de Haan, Arjan. "Migration and Livelihoods in Historical Perspective: A Case Study of Bihar, India." The Journal of Development Studies 38.5 (2002): 115-42. Print.

Deshingkar, P. "Internal Migration, Poverty and Development in Asia: Including the Excluded." IDS Bulletin 37.3 (2006): 88-100. Print.

FMIS. “History of Flood.” Flood Management Information System: Water Resources Department, Bihar 201120112006. 
Ghosh, Shubham. "Nitish Kumar Leading Bihar, Can Neighbour Mamata Learn?" oneindia news December 13 2012, sec. Feature. Print.

Gupta, Akhil. Postcolonial Developments : Agriculture in the Making of Modern India. Durham: Duke University Press, 1998. Print.

Harvey, C.F. “Groundwater Flow in the Ganges Delta." Science 296.5573 (2002): 1563-63. Print.

Henderson, J. V. “Cities and Development." Journal of Regional Science 50.1 (2010): 515-40. Print.

Huberman, Jenny. "Working and Playing Banaras: A Study of Tourist Encounters, Sentimental Journeys and the Business of Visitation." Dissertation. University of Chicago, 2006. Print.

India (Physiography). University of Texas at Austin, 2001.

Karim, M.F., and N. Mimura. "Impacts of Climate Change and Sea-Level Rise on Cyclonic Storm Surge Floods in Bangladesh." Global Environmental Change 18.3 (2008): 490-500. Print.

Kumar, A., et al. "Impact of Climate Change on Agriculture in Eastern Uttar Pradesh and Bihar States (India)." Mausam 62.2 (2011): 171-78. Print.

Kumar, A.K. Shiva. “Population and Human Development: Contemporary Concerns." Handbook of Population and Development in India. Eds. Kumar, A.K. Shiva, Pradeep Panda and Rajani R. Ved. New Delhi: Oxford University Press, 2010. 1-21. Print.

Kumar, Anand. "Paradoxes of Paradigm Shift: Indian Engagement with Liberalization and Globalization." Futures 40.8 (2008): 762-66. Print.

Mirza, M.M.Q., RA Warrick, and NJ Ericksen. "The Implications of Climate Change on Floods of the Ganges, Brahmaputra and Meghna Rivers in Bangladesh." Climatic Change 57.3 (2003): 287-318. Print.

Oberai, A. S., and H. K. Manmohan Singh. "Migration Flows in Punjab's Green Revolution Belt." Economic and Political Weekly 15.13 (1980): A2-A12. Print.

Pandit, K. “The Indian Landscape after Two Decades of Liberalization: An Introduction." Eurasian Geography and Economics 53.1 (2012): 1-6. Print.

Panter-Brick, Catherine. "Street Children, Human Rights, and Public Health: A Critique and Future Directions." Annual Review of Anthropology 31 (2002): 147-71. Print. 
Parliament, Indian. "Right of Children to Free and Cumpulsory Education Act 2012." Ed. Justice, Ministry of Law and. New Delhi2012. Print.

Sainath, Palagummi. "Crime \& No Punishment" Everybody Loves a Good Draught. New York: Penguin Books India, 1996. 263-64. Print.

---. "This Is the Way We Go to School." Everybody Loves a Good Drought. New York: Penguin Books India, 1996. 45-68. Print.

Sakha, Bal. Sitamarhi Study. Patna: Bal Sakha, 2012. Print.

Sharma, A.N. "Agrarian Relations and Socio-Economic Change in Bihar." Economic and Political Weekly (2005): 960-72. Print.

Shiva, Vandana. "The Green Revolution in Punjab." The Ecologist 21.2 (1991). Print.

----. The Violence of the Green Revolution: Third World Agriculture, Ecology, and Politics. London: Zed, 1991. Print.

Singh, Sukhpal. "Multi-national Corporations and Agricultural Development: A Study of Contract Farming in the Indian Punjab." Journal of International Development 14.2 (2002): 181-94. Print.

Som, S., M. Pal, and P. Bharati. "Role of Individual and Household Level Factors on Stunting: A Comparative Study in Three Indian States." Annals of Human Biology 34.6 (2007): 632-46. Print.

Steinberg, Jonah. "Runaway Train: Railway Children and Normative Spatialities in India." University of Vermont, 2012. 1-55 of Anthropology. Print.

Wilson, Kalpana. "Small Cultivators in Bihar and 'New'Technology: Choice or Compulsion?"Economic and Political Weekly 37.13 (2002): 1229-38. Print. 